\title{
Berbagi / Memberikan Bantuan Dimasa Pandemi Corona Kepada Masyarakat Yang Diperkirakan Terdampak Covid- 19 Di Desa Anjir Seberang Pasar 2 Kabupaten Batola
}

\author{
Abdul Wahab ${ }^{1}$,Rezky Nefianthi ${ }^{2}$, Arfie Yasrie ${ }^{3}$, Mahfuzil Anwar ${ }^{4 *}$ \\ 1,3,4 STIMI Banjarmasin, Indonesia, 70236 \\ 2 STIKIPP GRI Banjarmasin, Indonesia, 70121
}

*Email: manwar_stimi@yahoo.co.id

DOI : https://doi.org/10.37339/jurpikat.v1i3.410

Info Artikel:

Diterima :

15-12-2020

Diperbaiki :

17-12-2020

Disetujui :

18-12-2020
Abstrak: Salah satu dari Tridarma Perguruan Tinggi yang ketiga yaitu Pengabdian Kepada Masyarakat yang harus dilakukan bagi para Dosen, banyak hal yang dapat dilakukan seperti misalnya penyuluhanpenyuluhan, pelatihan-pelatihan serta bantuanbantuan soaial seperti yang dilakukan oleh sebagian dosen yang akan dilaporkan berupa laporan pengabdian masyarakat sebagai bukti bahwa Dosen secara perorangan maupun secara kelompok atau Tim telah melakukan pengabdian kepada masyarakat. Berdasarkan deskripsi permasalahan di atas, dapat disimpulkan bahwa kualitas dan kuantitas Tridarma Perguruan Tinggi salah satunya adalah Pengabdian Kepada Masyaraka merupakan pengembangan profesi dosen dimana kegiatan ini masih sangat dibutuhkan oleh sebagian bagi masyarakat, khususnya yang berkaitan dengan kondisi saat Pandemi Covid-19 ini yang sangat mengganggu berbagai sektor, misalnya sektor kesehatan, sektor ekonomi maupun sektor-sektor lainnya dampak dari Pandemi ini. Dalam sambutannya Ketua Tim Pengabdian Kepada Masyarakat Drs.H. Abdul Wahab, M.Si (STIMI Banjarmasin) berharap agar bantuan ini dapat bermanfaat bagi warga yang membutuhkan dan berdoa semoga Covid-19 ini segera berakhir serta kita sekalian dapat melakukan aktivitas seperti biasanya sebelum wabah Pandemi ini mengganggu kita dalam beraktivitas sebagaimana biasanya. Sebagaimana telah dikemukakan di atas, bahwa 
Kata Kunci : Pengabdian

Masyarakat dan Covid-19
Keywords: Community Service and Covid-19 perguruan tinggi melalui tenaga pendidiknya (Dosen) mengemban tiga tugas utama atau lebih populer dengan sebutan Tridarma Peguruan Tinggi, yaitu menyelenggarakan Pendidikan, melakukan Penelitian, dan Melaksanakan Pengabdian Kepada Masyarakat. Ketiga darma tersebut harus dilihat sebagai satu kesatuan yang utuh, dan tidak boleh dikotak-kotakkan secara terpisah. Oleh karenanyau, untuk memahami hakikat pengabdian kepada masyarakat, diperlukan pemahaman tentang dua darma yang lain. Tanpa melakukan darma pendidikan dan penelitian, tentu tidak akan ada hasil apapun yang dapat disampaikan kepada masyarakat.

Abstract: One of the third Tridarma Perguruan Tinggi, namely Community Service that must be done for Lecturers, there are many things that can be done such as counseling, training and social assistance such as those carried out by some lecturers who will be reported in the form of a service report. community as evidence that the Lecturer individually or as a group or team has performed community service. Based on the description of the problem above, it can be concluded that the quality and quantity of the Tridarma of Higher Education, one of which is Community Service, is a professional development for lecturers where this activity is still very much needed by some people, especially those related to the conditions during the Covid-19 Pandemic which is very disturbing. various sectors, for example the health sector, the economic sector and other sectors the impact of this pandemic. In his speech, the Head of Community Service Team, Drs.H. Abdul Wahab, M.Si (STIMI Banjarmasin) hopes that this assistance can be of benefit to residents in need and pray that Covid-19 will end soon and we can all carry out activities as usual before the pandemic outbreak disturbs us in our usual activities. As stated above, higher education through its educators (lecturers) carries out three main tasks or more popularly known as the Tridarma of Higher Education, namely organizing education, conducting research, and carrying out community service. The three dharmas must be seen as one unified whole, and should not be divided separately. Therefore, to understand the nature of community service, it is necessary to understand the other two dharmas. Without doing the darma of education and research, of course there will not be any results that can be conveyed to the public. 


\section{Pendahuluan}

Guru/Dosen adalah pendidik profesional. Hal ini sesuai dengan UndangUndang RI Nomor 20 Tahun 2003 tentang Sistem Pendidikan Nasional, Undangundang RI Nomor 14 Tahun 2005 tentang Guru dan Dosen, dan Peraturan Pemerintah RI Nomor 19 Tahun 2005 tentang Standar Nasional Pendidikan. Untuk itu, Dosen dipersyaratkan memiliki kualifikasi akademik minimal Sarjana Strata Dua (Magister) yang relevan dan menguasai kompetensi sebagai agen pembelajaran. Kualifikasi akademik minimal S2 dibuktikan dengan ijazah dan pemenuhan persyaratan relevansi mengacu pada jejang pendidikan yang dimiliki dan mata kuliah yang diampu/dibina, kompetensi profesional dibuktikan dengan diperolehnya sertifikat pendidik /Sertifikat Dosen (Serdos).

Sertifikasi Dosen dilakukan adalah sebagai upaya peningkatan mutu Dosen yang dibarengi dengan peningkatan kesejahteraan Dosen, diharapkan dapat meningkatkan mutu pembelajaran dan mutu pendidikan di Indonesia secara berkelanjutan. Bentuk peningkatan kesejahteraan Dosen berupa pemberian tunjangan profesi sebesar satu kali gaji pokok bagi Dosen yang memiliki Sertifikat Dosen (Serdos). Tunjangan tersebut berlaku, baik bagi Dosen yang berstatus PNS Dpk (Pegawai Negeri Sipil Diperbantukan) maupun bagi Dosen yang berstatus pegawai/DosenYayasan bukan Dosen sebagai pegawai negeri sipil (swasta).

Peraturan Menteri Pendidikan Nasional (Permendiknas) Nomor 18 Tahun 2007 menyatakan bahwa sertifikasi bagi dosen dalam jabatan dilaksanakan melalui uji kompetensi untuk memperoleh Sertifikat Dosen, yang harus melalui beberapa tahapan ujian sehingga ditentukan sesorang lulus untuk mendapatkan Sertifikat Dosen (Serdos) yang menunjukan keprofesionalan seseorang sebagai tenaga pendidik (Dosen).

Peningkatan profesionalitas dosen dapat dimotivasi secara internal maupun eksternal. Program sertifikasi dosen merupakan salah satu wujud motivasi eksternal dari pemerintah yang digunakan untuk memperbaiki profesionalitas dosen. Dari sekian unsur penilaian, secara umum ditemukan bahwa komponen dari Tridarma Perguruan Tinggi yaitu 1) Pendidikan dan Pengajaran 2) Melaksanakan Penelitian dan 3) Pengabdian Kepada Mayarakat. Karya Ilmiah berupa pelaksanaan penelitian merupakan pengembangan dosen yang diwujudkan berupa penulisan karya ilmiah yang harus dipublikasikan baik secara nasional maupun internasional.

Salah satu dari Tridarma Perguruan Tinggi yaitu Tridarma yang ketiga adalah Pengabdian Kepada Masyarakat yang harus dilakukan bagi setiap Dosen, banyak hal yang dapat dilakukan seperti misalnya penyuluhan-penyuluhan, pelatihan-pelatihan serta bantuan-bantuan soaial seperti yang dilakukan oleh sebagian dosen yang akan dilaporkan berupa laporan pengabdian masyarakat sebagai bukti bahwa Tim telah melakukan pengabdian masyarakat.

Berdasarkan deskripsi permasalahan di atas, dapat disimpulkan bahwa kualitas dan kuantitas Tridarma Perguruan Tinggi salah satunya adalah 
Pengabdian Kepada Masyaraka merupakan pengembangan profesi dosen yang saat ini masih sangat dibutuhkan bagi masyarakat yang terdampak Covid-19 ini, terutam saat Pandemi Covid-19 ini yang sangat mengganggu sektor kesehatan, sektor ekonomi maupun sektor-sektor lainnya.

\section{Metode}

Dalam rangka membantu masyarakat di masa Pandemi Virus Corono (Covid-19) ini Sekolah Tinggi Ilmu Manajemen Indonesia (STIMI) Banjarmasin, bekerja sama dengan Sekolah Tinggi Ilmu Keguruan dan Ilmu Pendidikan (STIKIP) PGRI Banjarmasin, melalui beberapa orang dosen diantaranya :

Drs. H. Abdul Wahab,MSi (STIMI), Dr. Hj. Rezky Nefianthi, M.Si (STIKIP PGRI), Arfie Yasrie, SE, MM (STIMI) ketiganya merupakan Dosen dengan status PNS Dpk dan Dr. Mahfuzil Anwar, SE,MM (STIMI) merupakan dosen Yayasan, Tim ini telah melaksanakan salah satu dari Tridharma Perguruan Tinggi yaitu Pengabdian Kepada Masyarakat dalam bentuk Bakti Sosial dengan tema :

“ Berbagi/memberikan bantuan dimasa Pendemi Corona kepada masyarakat yang diperkirakan terdampak Covid-19".

Kegiatan Bakti Sosial ini dilaksanakan di Desa Anjir Seberang Pasar II Kecamatan Anjir Pasar, Kabupaten Barito Kuala, Provinsi Kalimantan Selatan.

Adapun profil dari objek pelaksanaan Bakti Sosial ini sebagai berikut :

$\begin{array}{ll}\text { Provinsi } & \text { : Kalimantan Selatan } \\ \text { Kabupaten } & \text { : Barito Kuala } \\ \text { Kecamatan } & \text { : Anjir Pasar } \\ \text { Desa } & \text { : Anjir Seberang Pasar II } \\ \text { Kepala Desa } & \text { : Sayuti } \\ \text { Sekretaris Desa } & : \text { Muhammad Sya'rani } \\ \text { Luas Desa } & : 1.120 .000 \mathrm{M} 2 \\ \text { Jumlah Penduduk } & : \text { 1.137 Jiwa } \\ & : \text { Laki-laki =542 orang } \\ & : \text { Perempuan }=595 \text { orang } \\ \text { Jumlah KK } & : \text { 375 KK } \\ \text { Jumlah RT } & : \text { RT }\end{array}$

Sedangkan kegiatan ini dilaksanakan pada beberapa waktu pelaksanaan pada hari dan tanggal yang berdeda yaitu:

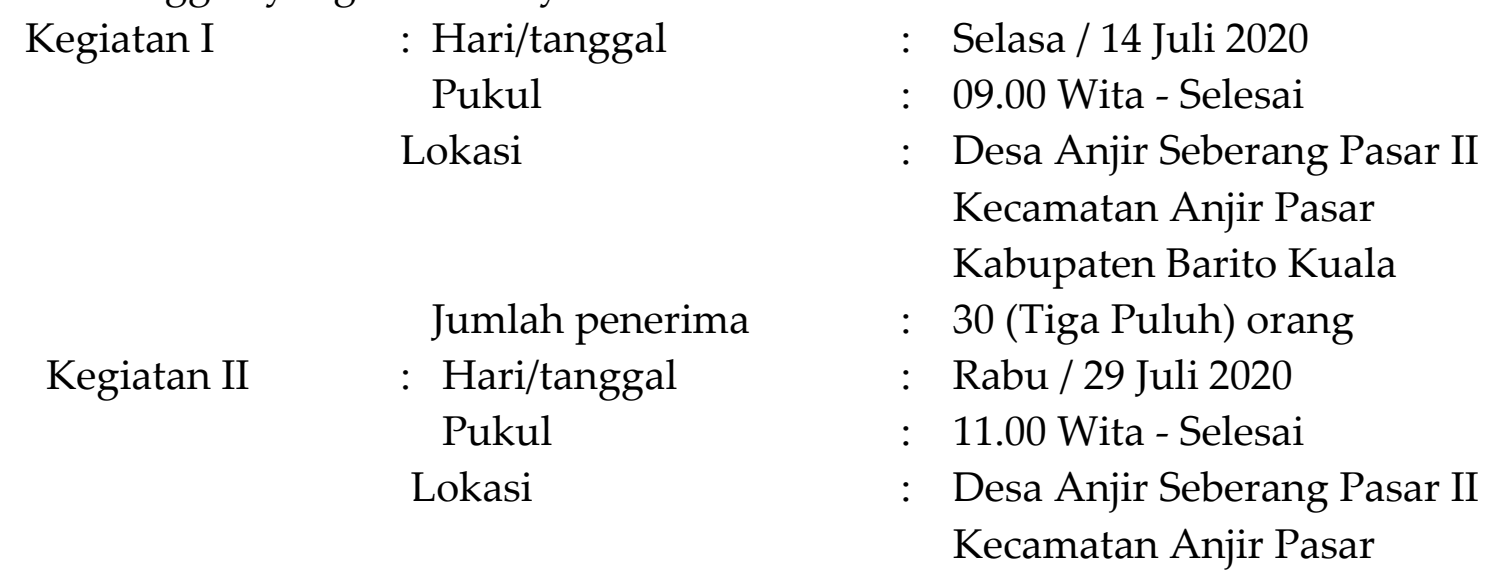




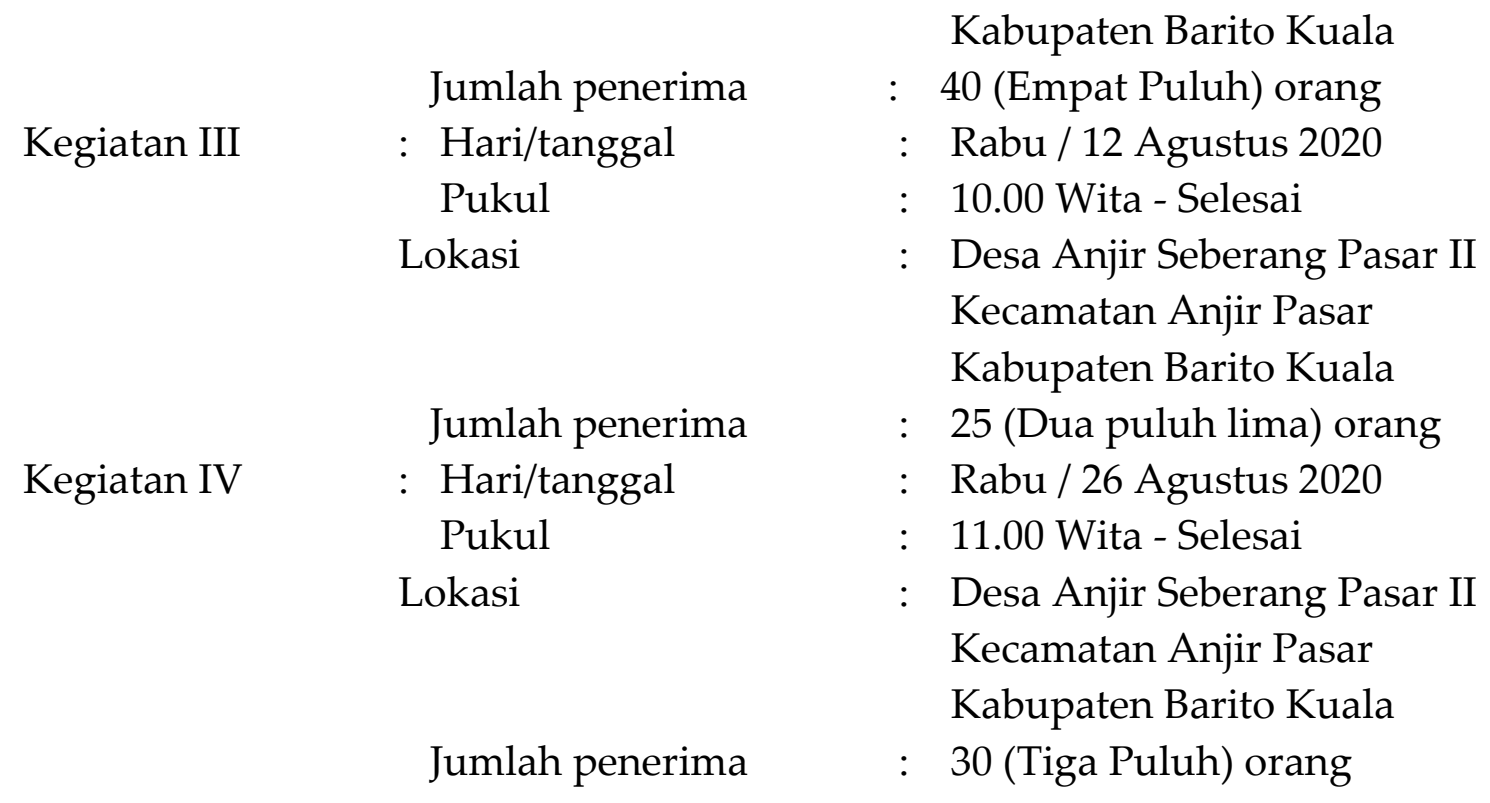

Sebagai Ketua dari Bakti Sosial ini dipimpin oleh Drs.H. Abdul Wahab, M.Si pada kesempatan itu Ketua Tim menyampaikan bahwa Bakti soaial yang dilakukan dengan memberikan bantuan Sembako yang dikemas dalam bungkusan plastik, jangan dinilai dari besar/kecilnya bantuan yang diberikan namun harapannya adalah dapat meringankan sebagian kecil beban yang dirasakan. Bantuan sebagian diserahkan langsung kepada warga, sebagian lagi diserahkan kepada Pengurus Desa / Ketua RT untuk dibagikan kepada warga yang terdampak oleh Pandemi Covid-19 yang telah berjalan beberapa bulan terakhir ini, berharap dapat membantu dan meringankan beban masyarakat yang terdampak oleh Pandemi ini, yang pada kenyataannya sangat mengganggu aktivitas mereka sehari-hari terutama bagi para Lansia. Kegiatan inipun disambut dengan sukacita oleh masyarakat setempat terlebih oleh warga yang terdampak Pandemi Covid-19.

Diakhir sambutannya Ketua Tim Pengabdian Kepada Masyarakat Drs.H. Abdul Wahab, M.Si (STIMI Banjarmasin) berharap agar bantuan ini dapat bermanfaat bagi warga yang membutuhkan dan berdoa semoga Covid-19 ini segera berakhir serta kita sekalian dapat melakukan aktivitas seperti biasanya sebelum wabah Pandemi ini mengganggu kita dalam beraktivitas sehari-hari.

\section{Hasil Dan Pembahasan}

Pengabdian kepada masyarakat oleh perguruan tinggi masih belum banyak dilaksanakan terutama pada fungsi pengembangan, penerapan dan pemanfaatan salah satu dari Tridarma Perguruan Tinggi selain Melaksanakan Pendidikan dan Melakukan Penelitian yang menghaslkan Karya Ilmiah yang berdampak pada dunia pendidikan maupun dunia bisnis dan lain-lain. (Sutrisno, 1996). Demikian pula yang menjadi objek sasaran lebih tertuju pada masyarakat pengguna golongan tertentu yang pada umumnya memerlukan bantuan secara gratis. Hal ini mungkin merupakan akibat dari kekeliruan dalam memberikan pengertian "pengabdian kepada masyarakat" hanya sebagai "kegiatan tanpa pamrih", 
sehingga khalayak yang menjadi sasaran para pelaku kegiatan pengabdian kepada masyarakat ini dengan sendirinya adalah mereka (golongan masyarakat) yang mengharapkan bantuan secara gratis pula. Akibatnya, kegiatan pengabdian kepada masyarakat yang selama ini banyak dilaksanakan, baik oleh Dosen PTN maupun Dosen PTS, cenderung mengarah pada kegiatan pelayanan kepada masyarakat yang dilakukan secara cuma-cuma, apalagi dimasa pandemi Covid-19 sekarang ini.

Secara organisasional pun, masih terdapat anggapan atau persepsi yang salah, seolah-olah lembaga yang berwenang dan bertanggungjawab untuk melaksanakan kegiatan pengabdian kepada masyarakat adalah Lembaga Pengabdian Kepada Masyarakat (atau apapun namanya) yang telah dibentuk oleh sebuah Perguruan Tinggi, padahal dalam PP No.30/1990 pasal 43 ayat 1 telah disebutkan dengan jelas bahwa pengabdian kepada masyarakat dapat dilaksanakan oleh perguruan tinggi melalui lembaga pengabdian kepada masyarakat, pusat penelitian, jurusan, laboratorium, kelompok maupun perorangan. Hal ini mungkin disebabkan oleh tidak adanya Job Discription (petunjuk pekerjaan) yang secara eksplisit menunjukkan tugas dan kewajiban untuk melaksanakan pengabdian kepada masyarakat bagi unit-unit organisasi selain Lembaga Pengabdian Kepada Masyarakat sebagaimana disebutkan di atas, sehingga masing-masing unit organisasi itu hanya menjalankan tugas dan kewajibannya secara fungsional saja.

Sebagaimana telah dikemukakan di atas, bahwa perguruan tinggi melalui tenaga pendidiknya (Dosen) mengemban tiga tugas utama atau lebih populer dengan sebutan Tridarma Peguruan Tinggi, yaitu menyelenggarakan Pendidikan, melakukan Penelitian, dan pengabdian kepada masyarakat. Ketiga darma tersebut harus dilihat sebagai satu kesatuan yang utuh, dan tidak boleh dikotak-kotakkan secara terpisah. Oleh sebab itu, untuk memahami hakikat pengabdian kepada masyarakat, diperlukan pemahaman tentang dua darma yang lain. Tanpa melakukan darma pendidikan dan penelitian, tentu tidak akan ada hasil apapun yang dapat disampaikan kepada masyarakat.

Kualitas pelaksanaan setiap darma saling bergantung antara satu dengan yang lain : kualitas pendidikan dan pengajaran akan mempengaruhi kualitas penelitian, dan kualitas penelitian akan mempengaruhi kualitas pengabdian kepada masyarakat, demikian pula sebaliknya. Oleh sebab itu, penyelenggara dan pengelola perguruan tinggi harus memandang Tridarma Perguruan Tinggi tersebut sebagai satu kesatuan yang utuh dan tidak terpisah, sehingga tidak perlu menunjuk mana darma yang lebih penting dan darma yang kurang penting. Hal ini perlu dipahami, karena keberhasilan perguruan tinggi dalam menjalankan kegiatan akademiknya, dapat dinilai dari kualitas pendidikan, penelitian, serta pengabdian kepada masyarakat, secara bersama-sama.

Secara filosofis, pengertian tentang pengabdian kepada masyarakat dapat berkembang dan dikembangkan, sesuai dengan persepsi dan tergantung pada dimensi ruang dan waktu. Koswara (1989) menyatakan bahwa pengabdian kepada masyarakat oleh perguruan tinggi adalah pengamalan IPTEKS yang dilakukan oleh perguruan tinggi secara melembaga melalui metode ilmiah langsung kepada 
masyarakat yang membutuhkannya, dalam upaya mensukseskan pembangunan dan mengembangkan manusia pembangunan menuju tercapainya manusia Indonesia yang maju, adil dan sejahtera.

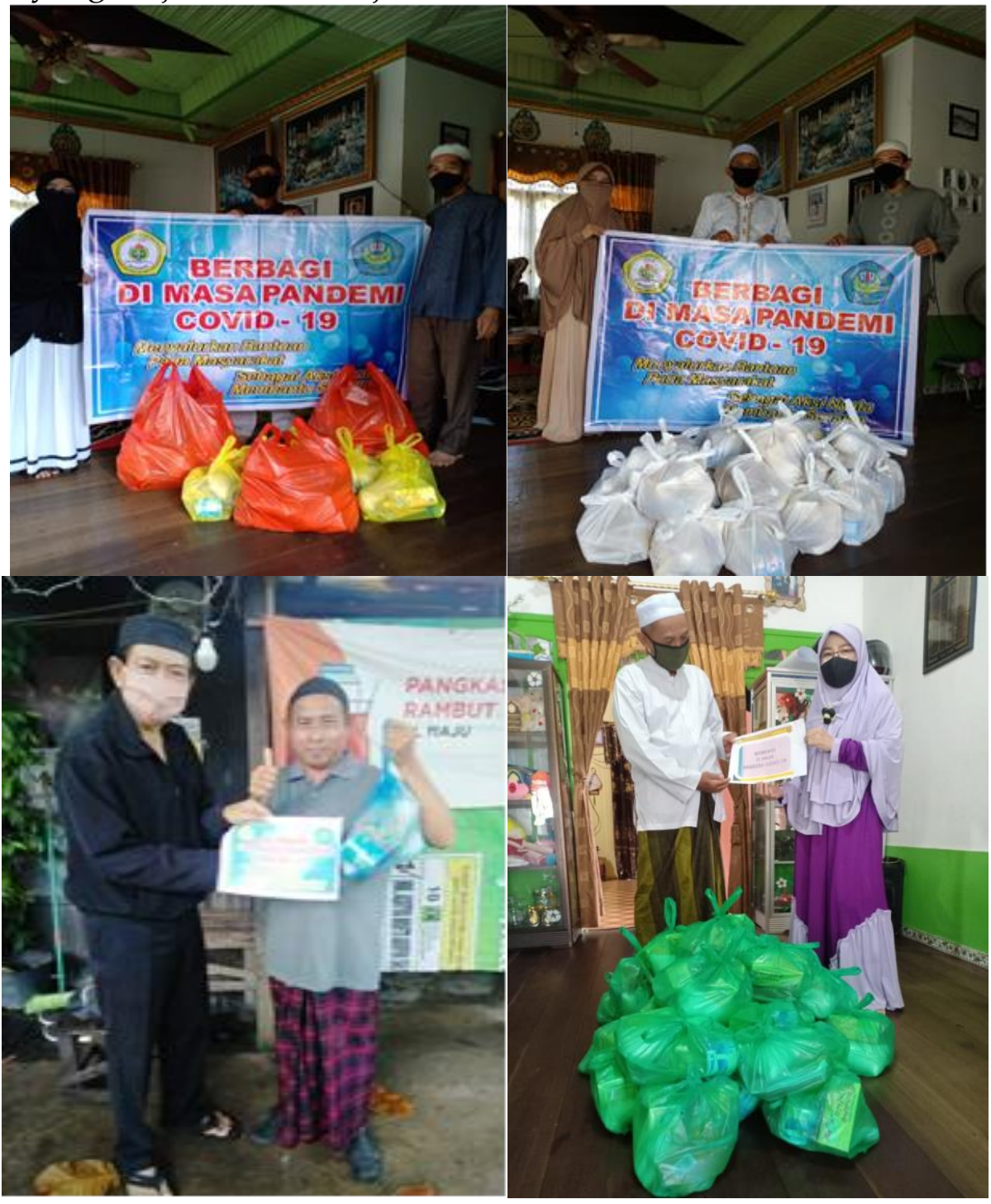

Gambar 1 rangkai kegiatan

\section{Kesimpulan}

Berdasarkan uraian-uraian di atas, maka kegiatan pengabdian kepada masyarakat sesuai dengan bentuk yang relevan dengan pola ilmiah pokok yang dijalankan. Pelaksanaan kegiatan pengabdian kepada masyarakat oleh STIMI Banjafmasin dan STIKIP PGRI Banjarmasin tidak harus menjadi tugas dan tanggungjawab Lembaga Pengabdian Kepada Masyarakat (LPM) saja. UPT-UPT lain juga mempunyai tugas dan tanggungjawab yang sama, sesuai dengan bentuk kegiatan pengabdian kepada masyarakat yang dapat dijalankannya. Dalam kegiatan pengabdian kepada masyarakat, LPM dapat bertindak sebagai koordinator kegiatan, yang melakukan perencanaan, pemantauan dan pengendalian kegiatan pengabdian. pelayanan kepada masyarakat dapat dilaksanakan oleh LPM. 


\section{Ucapan Terima Kasih}

Kepada Ketua STIMI Banjarmasin dan Ketua STIKIP PGRI Banjarmasin yang telah memberi kesempatan dan memberi ijin kepada Dosennya untuk melaksanakan pengabdian kepada masyarakat, Kepala Desa Bapak Sayuti dan Sekretaris Desa Bapak Muhammad Sya'rani serta para ketua RT yang berkenan membantu menyalurkan bantuan yang diberikan kepada masyarakat khususnya para kaum Lansia yang berada dilingkungan desa yang dibawahinya. Pihak-pihak yang membantu kelancaran terlaksananya Pengabdian Kepada Masyarakat ini sehingga kegiatan ini berjalan sesuai dengan yang direncanakan.

\section{Referensi}

Direktorat Jenderal Pendidikan Tinggi. 2007. Panduan Penyusunan Perangkat Portofolio Sertifikasi Dosen dalam Jabatan. Jakarta: Depdiknas.

Direktorat Jenderal Pendidikan Tinggi. 2007. Pedoman Penetapan Peserta dan Pelaksanaan Sertifikasi Dosen dalam Jabatan. Jakarta: Depdiknas.

Direktorat Jenderal Pendidikan Tinggi. 2007. Pedoman Sertifikasi bagi Dosen dalam Jabatan, Jakarta: Depdiknas.

Peraturan Pemerintah RI Nomor 4 tahun 2014 tentang Penyelenggaraan Pendidikan Tinggi dan Pengelollan Perguruan Tinggi.

Undang Undang Republik Indonesia No. 20 Tahun 2003 Tentang Sistem Pendidikan Nasional.

1989, Undang Undang Republik Indonesia No. 2 Tahun 1989 Tentang Sistem Pendidikan Nasional.

1990, Peraturan Pemerintah Republik Indonesia No. 30 Tahun 1990 Tentang Pendidikan Tinggi.

Ditbinlitabmas, 1996, Pedoman Pelaksanaan Penelitian dan Pengabdian Kepada Masya- rakat Oleh Perguruan Tinggi, Ditjen Dikti, Jakarta.

Harijono, 1996, Action Research sebagai refleksi kegiatan pengabdian kepada masyara- kat secara ilmiah, LPM Universitas Brawijaya, Malang.

Slamet, M. (Ed.), 1986, Metodologi Pengabdian Kepada Masyarakat Oleh Perguruan Tinggi, Edisi ke3, Universitas Lampung, Bandar Lampung.

Sucipto, Pengabdian Kepada Masyarakat Melalui Kuliah Kerja Nyata, Pelatihan 
Metodo- logi Pengabdian Kepada Masyarakat Bagi Dosen PTN dan PTS seJawa Timur 1921 Nopember 1996, LPM Universitas Brawijaya, Malang.

Sutrisno, C.Imam, 1996, Hakikat dan Prinsip Pengabdian Kepada Masyarakat Oleh Per- guruan Tinggi, Pelatihan Metodologi Pengabdian Kepada Masyarakat Bagi Dosen PTN dan PTS seJawa Timur 1921 Nopember 1996, LPM Universitas Brawijaya, Malang.

1996, Metode Pengabdian dan Teknik Penyusunan Proposal Penerapan IPTEKS dan Program Vucer, Pelatihan Metodologi Pengabdian Kepada Masyarakat Bagi Dosen PTN dan PTS seJawa Timur 1921 Nopember 1996, LPM Universitas Brawijaya, Malang.

1996, Pengabdian Kepada Masyarakat Oleh Perguruan Tinggi, Penataran Metodologi Pengabdian Kepada Masyarakat di Lingkungan Universitas Airlangga, LPM UNAIR, Surabaya. 